\title{
A REVIEW OF THE NASA TEXTILE COMPOSITES RESEARCH
}

\author{
C. C. Poe, Jr. ${ }^{*}$, H. B. Dexter ${ }^{*}$, and I. S. Raju ${ }^{\dagger}$ \\ NASA Langley Research Center \\ Hampton, Virginia 23681-0001
}

\begin{abstract}
During the past 15 years NASA has taken the lead role in exploiting the benefits of textile reinforced composite materials for application to aircraft structures. The NASA Advanced Composites Technology (ACT) program was started in 1989 to develop composite primary structures for commercial transport airplanes with costs that are competitive with metal structures. As part of this program, several contractors investigated the cost, weight, and performance attributes of textile reinforced composites. Textile composites made using resin transfer molding type processes were evaluated for numerous applications. Methods were also developed to predict resin infiltration and flow in textile preforms and to predict and measure mechanical properties of the textile composites. This paper describes the salient results of that program.
\end{abstract}

\section{Introduction}

The NASA Advanced Compopsites Technology program was started in 1989 to develop composite primary structures for commercial transport airplanes with costs that are competitive with those of current metallic airplanes. Textile composites were considered for many components to improve structural performance and to reduce costs. Boeing and Lockheed-Martin evaluated textile composites for fuselage frames, window belt reinforcements, and various keel components of the fuselage. Northrop-Grumman evaluated textile concepts for making stiffened skins using 3-D textile composites, and McDonnell Douglas evaluated knitted, braided, and stitched textile fabrics for a wing box.

The NASA in-house program, in conjunction with university research grants focused on the development of analytical models to predict resin infiltration and flow in textile preforms, development of a

\footnotetext{
"Senior Research Engineer, Mechanics of Materials Branch.

${ }^{\dagger}$ Head, Mechanics of Materials Branch, Associate Fellow.

Copyright (c) 1997 by the American Institute of Aeronautics and Astronautics, Inc. No copyright is asserted in the United States under Title 17, U. S. Code. The U. S. Government has a royaltyfree license to exercise all rights under the copyright claimed herein for Governmental Purposes. All other rights are reserved by the copyright owner.
}

database on damage tolerance and mechanical properties of new material forms, development of analytical models to predict elastic properties and strength of textile reinforced composite materials, and development of test methods for textile composites.

This papers summarizes the results of the ACT textile composites program. Included are discussions on the application of textile composites to primary structural components, mechanics methodologies to predict textile material response, test methods to measure material properties, experimental methods to measure compaction and permeability behavior of textile preforms, and analytical methods to predict resin flow in textile preforms.

\section{Textile Composite Applications}

Textile material forms that have shown the highest potential for application to composite airframe structures are shown in Fig. 1. Fig. 2 indicates some of the advantages and limitations of each of the textile material forms of interest. Although each of these materials can meet a specific need, the material forms that created the most interest were triaxial braiding for complex structural shapes, multiaxial warp knitting for large area coverage, and stitching for improved damage tolerance.

\section{Fuselage Structures}

During Phases A and B of the NASA ACT program, trade studies were conducted to determine which structural elements could benefit the most from the use of textile composite materials. Fig. 3 shows typical fuselage structural elements that were selected to determine the applicability of textile material preforms and fabrication methods. The structural elements included stiffened side panels, circumferential frames, keel beam frames, and window belts. These structural elements are briefly discussed below.

A fuselage side panel with stiffeners and frames is shown in Fig. 4. Using innovative 3-D weaving technology both the frames and the stiffeners are woven with continuous fibers in both directions. Since the weaving process selected can only weave in the $0^{\circ}$ and $90^{\circ}$ directions, additional $\pm 45^{\circ}$ material had to be stitched onto the base fabric to 
provide the shear load carrying capability. Stitching was performed with Kevlar 29 type thread and a resin film infusion process was used to infiltrate the preform.

Curved structures with integral flanges can be made using 2-D triaxial braiding and 3-D throughthe-thickness braiding concepts. These braiding concepts were chosen by Boeing ${ }^{1}$ and Lockheed Martin $^{2}$ to manufacture circumferential frames. The flanges of these frames are produced by braiding in pockets or bifurcations that could be folded out prior to resin application as shown in Fig. 5. Matched-metal tooling and resin transfer molding were selected to produce composite frames for structural evaluations.

Thick beams and frames were used near the keel of the fuselage. Design considerations for keel beam frames are impact damage tolerance, through penetration, damage containment, and durability. The 2-D triaxial braiding and resin transfer molding (RTM) fabrication processes were used to fabricate the curved frames for structural testing. Several frames that are bonded to a curved honeycomb sandwich keel panel are shown in Fig. 6 .

Design considerations for the window belt shown in Fig. 3 are out-of-plane interlaminar stresses, stability under combined loads, and damage tolerance and pressure containment. Design concepts with through-the-thickness reinforcement were selected. Both powder coated and RTM fabrication concepts were used. Several woven and braided fuselage window frames are shown in Fig. 7.

\section{Wing Structures}

Some of the wing structural elements chosen to determine the applicability of specific textile material forms and fabrication processes are shown in Fig. 8. For wing structures, the design considerations are strength, stiffness, impact and discrete source damage. In addition, design should account for joints, access doors, bearing, and openhole strength, out-of-plane loads, high load introduction points, such as landing gear attachments, and lightning strike protection. Through extensive testing, NASA has determined that through-thethickness stitching of dry textile preforms is an effective way to achieve improved damage tolerance. Various factors that can influence the effectiveness of stitching such as the stitch type, thread type, and stitch spacing were studied. Early research focus was on improvement of compression after impact damage tolerance compared to laminated tape composites. Later studies focused on processing, manufacturing, and assembly issues.
Fig. 9 presents the compression after impact results on stitched uniweave fabrics, unstitched prepreg tape, and toughened matrix composite systems. The results indicate that for an unstitched brittle composite system, AS4/3501-6, the compression strength drops from $600 \mathrm{MPa}$ to approximately $140 \mathrm{MPa}$ due to a $68 \mathrm{~J}$ impact. The results for the toughened matrix composite system indicates a significant improvement in CAI strength compared to the unstitched brittle material, but the toughened materials are 2 to 3 times more expensive. In contrast, the stitched composite demonstrates a significant increase in CAl strength compared to the unstitched AS4/3501-6 composite (see the upper curve in Fig. 9). The results of these and other tests led McDonnell Douglas to select through-the-thickness stitching of dry textile preforms as the baseline for their advanced wing fabrication studies.

Blade stiffeners and integral spar caps were used as integral stiffening elements for the upper and lower wing covers (see Fig. 8). The stiffeners are fabricated by stacking tubular fabrics and partially stitching them together to form the vertical (upstanding) blade. The unstitched portion of the tubular fabrics are folded left and right to form the stiffener flanges. The stiffener flanges are stitched to the wing skin material to form an integral structure that can be infused with resin in one autoclave operation. A similar assembly concept is also used for the wing box intercostal clips. These clips attach rib structure to the wing cover panels. The intercostal clips need to be designed to transfer compressive crushing and tensile fuel pressure loads. Flanges on the skin side of the clips are folded and stitched to the wing skin and flanges on each end of the clips are attached to the blade stiffener webs as shown in Fig. 10. Existing stitching machines only stitch vertically and the intercostal clip to stiffener web attachments require horizontal stitching. To perform this operation, alternate attachment concepts are being studied.

\section{Processing Science}

\section{Analytical Modeling}

To eliminate trial and error processes, analytical models are required to predict resin flow into textile preforms. The models must be verified through experiments if they are to be used with confidence. Three-dimensional models are required to adequately capture response of complex preforms such as wing cover panels that contain stitched/knitted fabric skins and stitched/braided stiffeners. The objectives of the analytical models are to predict resin flow and cure as a function of 
time. The various elements of the NASA processing science program for textile reinforced composites are shown in Fig. 11. A 3-D process simulation model is being developed under NASA grant to Virginia Polytechnic Institute. ${ }^{3}$ Major submodels include resin flow, heat transfer, and thermochemical. A schematic of a 3-D finite element model for infusion of a blade stiffener, including the tooling, is shown in Fig. 12. The preform, aluminum tooling, graphite caul sheet, and resin are included in the model.

Textile preforms are complex and permeability depends on both the direction of resin flow and the degree of deformation of the fabric. Since analytical models are not available to predict permeability and compaction response of textile preforms, precise experiments must be conducted to acquire coefficients for use in the analytical models. In addition, cure kinetics of the resin must be characterized for input to the analytical models.

\section{Textile Preform Characterization}

Experimental methods have been developed to measure fiber volume fraction as a function of compaction pressure and permeability as a function of fiber volume fraction. For stitched preforms, compaction and permeability are a function of the stitch density and stitch tension. Fig. 13 shows compaction and permeability data for an unstitched multiaxial warp knitted fabric. ${ }^{3}$ The data shown in Fig. 13 indicates that about $175 \mathrm{kPa}$ of pressure is required to obtain a 60-percent fiber volume fraction and the permeability of the fabric is reduced by about 50-percent as the fiber volume fraction increases from 55-to 65-percent.

\section{Mechanics of Textile Composites}

Laminates made from unidirectional layers have no fibers in the thickness direction. The layers are usually prepreg tape. On the other hand, textile composites are characterized by their 3-D architecture. The interlacing yarns of some textiles pass completely through the textile and give true through-the-thickness reinforcement. However, for some textiles, contiguous layers are interlaced by yarns, which do not pass completely through the textile but still the interlacing yarns must be severed to separate the layers. Some textile composites are made from stacks of fabric and do not have complete through-the-thickness reinforcement. These quasi-laminar textiles are often treated using classical lamination theory and sometimes referred to as 2-D textiles.

Textiles have periodic geometry that is dictated by the type of yarns and machines used to make the textile. A unit cell is the smallest geometric ele- ment that can be used to represent the periodic textile geometry by spatially translating unit cells without rotations or reflections. The field of inplane normal displacements in the loading direction of a tension coupon is shown in Fig. 14 for a triaxial braid. ${ }^{4}$ In a triaxial braid, the braider yarns are braided about fixed (straight) yarns. The fixed yarns in Fig. 14 are perpendicular to the loading direction. The unit cell is $11.9 \mathrm{~mm}$ long and 5.4 $\mathrm{mm}$ wide. For uniform displacements (constant strain), the Moiré lines (fringes) would be straight and equally spaced. Instead, the lines are wavy, and the locations of the yarns are evident in the pattern of waviness. The joggles in the fringes are caused by intense shearing in regions of high resin content between the surface braider yarns. The rotations (shearing) reverse where the braider yarns cross one another. Normal strain varies inversely with line spacing. Thus, the normal strains are highest over the fixed yarns and lowest where the braider yarns cross. The average strains in these two regions differ by a factor of three.

The nonuniform strain field in Fig. 14 raised concerns about test methods being adequate to measure bulk or average mechanical properties, notched strength, and damage tolerance behavior of textile composites. This high level of inhomogeneity guided planning of the program to develop a basic mechanics underpinning for the textile composites.

The Mechanics of Textile Composites Program had the following three objectives: (1) to develop test methods or to modify existing test methods to measure mechanical properties and design allowables, (2) to develop mechanics models to predict the properties of the textile composite from the properties of its constituents and the fiber architecture, and (3) to develop a coupon-type test data base for textile composites. ${ }^{5}$ Results of each of the investigations are briefly reviewed below.

\section{Test Methods}

A survey of commonly used test methods to derive design allowables for laminated prepreg tape composites was undertaken by Masters and Portanova. ${ }^{6}$ The objective of this survey was to determine the minimum test methods that should be evaluated for textile composites. The test methods in Fig. 15 were evaluated by conducting tests on various textiles. The best of the test methods are also given in Fig. 15. They were determined on the basis of low coefficient of variability, appropriate failure mode, and simplicity. None of the inplane shear test methods was found to be satisfactory to measure strength. Some other interlaminar test methods were evaluated for tension, 
compression, shear, and fracture toughness. ${ }^{7}$ Some gave reasonable results for the quasilaminar textiles, but most were difficult to conduct or gave unacceptable results for the 3-D textiles.

Because of the potential for a very nonhomogeneous strain field as shown in Fig. 14, a study was made to determine the effect of strain gage size on strain measurements. The ratio of modulus from strain gages to that from extensometers is plotted against the ratio of strain gage length to unit cell length in Fig. 16. The modulus is for the loading direction. The gage length for the extensometer was $25 \mathrm{~mm}$, and the strain gage sizes ranged from 3.2 by $1.6 \mathrm{~mm}$ to 12.7 by $12.7 \mathrm{~mm}$. Measurements were made on four triaxial braided composites. The difference between strain gages and extensometer decreased with strain gage length. For strain gages longer than the unit cell, the difference was +4 to $-6 \%$.

Net tension strengths are plotted in Fig. 17 for two triaxial braids and two equivalent tape laminates. ${ }^{8}$ Some coupons contained 2.5-cm-diameter holes and some contained no holes. The braid angle and fraction of fixed (axial) yarns was $70^{\circ}$ and $46 \%$, respectively, for both braids. However, the yarns used in making LLL contained 2.5 times as many filaments as those used in making SLL. (The notation $\left[0_{30 k} / \pm 70_{6 k}\right]$ in Fig. 17 indicates $30 \mathrm{k}$ fixed yarns and $6 \mathrm{k}$ braider yarns.) The areal weights of the $0^{\circ}$ and $\pm 70^{\circ}$ plies in the equivalent laminates were approximately equal to those of the fixed and braider yarns, respectively, in the braids. The plies were also thicker in the LLL equivalent tape laminate than the SLL laminate to simulate the larger yarns in the braid. The unnotched strength of the SLL and LLL braids were $11 \%$ and $33 \%$ less, respectively, than those of the equivalent tape laminates. On the other hand, the open-hole strengths of the SLL and LLL braids were only $2 \%$ and $12 \%$ less, respectively, than those of the equivalent tape laminates. The strength reductions were due to the yarn crimp introduced by interlacing in the braiding process. The reductions were greater for the LLL braids than the SLL braids due to the larger crimp associated with the larger yarns. The strengths of the LLL equivalent tape laminates were about the same as those of the SLL equivalent tape laminates. Stiffness of the SLL and LLL braids were reduced much less by crimp than the unnotched strengths. The modulus of the LLL braid was about $92 \%$ of that predicted for the tape laminate, and the modulus of the SLL braid was about $100 \%$ of that predicted for the tape laminate.
Radiographs of specimens like those in Fig. 17 with open holes are shown in Fig. 18. The specimens were loaded to approximately $75 \%$ of their ultimate load before $x$-raying, and then an x-ray opaque dye penetrant was applied to the composites to better reveal the damage. Cracking patterns in the matrix were similar for the braids and equivalent tape laminates. The cracks were deeper and more intense in radiographs of the composites with thicker plies and larger yarns.

Similar results were also obtained by Boeing for triaxial braids and equivalent tape laminates. ${ }^{9}$ The test methods included

- unnotched tension, compression, and shear

- open-hole tension and compression

- filled-hole tension

bolt bearing

The specimens were loaded both parallel and perpendicular to the fixed yarns.

Through-the-thickness strengths are plotted in Fig. 19 for tape laminates and quasi-laminar 2-D textiles. ${ }^{10}$ The bars represent mean values, and the tick marks below and above the bars represent extreme values. The strengths were calculated from bend tests. These 2-D textiles failed in the bend regions from circumferential (interlaminar) cracks much as the tape laminates. The strengths for the 2-D textiles and the 48-ply AS4/3501-6 tape laminates were the lowest, those for the AS4/8551-7 toughened tape laminates were intermediate, and those for the 24-ply AS4/3501-6 tape laminates were the highest. Strengths for the 24-ply AS4/3501-6 tape laminates were high probably because of large fiber volume fractions. Fiber volume fractions for the 24-ply AS4/3501-6 tape laminates were about $62 \%$, and those for the other composites ranged from $50 \%$ to $55 \%$. Thus, taking into account fiber volume fraction, resin toughness had more influence on through-thethickness strength than the 3-D nature of the layers.

3-D weaves were also tested, but radial cracks developed in the bend region, making strength calculations suspect. ${ }^{10}$ However, when all the composites were ranked according to bending moment at failure normalized by width and thickness, the 3-D weaves were the lowest.

For low impacter velocities (no viscoelastic behavior) and large impacter masses (relative to target mass), impact behavior is quasi-static. ${ }^{11}$ Thus, a static indentation (SI) test can be used to measure a composite's damage resistance. (The static indentation test is currently being considered by the American Society for Testing and Materials (ASTM) 
for a standard test method.) The contact force is plotted against indenter displacement in Fig. 20 for a non-stitched and stitched 16-ply AS4/3501-6 quasi-isotropic composite plate. The layers were uniweave fabric. The composite plate was clamped between two metal plates with concentric circular openings. The indenter was mounted in a universal testing machine. The discontinuities in the curve are caused by the development and spread of damage. The first indication of damage is labeled $F_{1}$. The specimen was unloaded after widespread damage but before penetration. One major advantage of the SI test is that the impact force and state of damage can be controlled. Also, the impact energy for an equivalent drop weight test can be calculated by integrating the force displacement curve. This procedure was used by Portanova to determine drop weight energies to produce specific dent depths, ranging from barely visible to readily visible. ${ }^{12}$

Delamination diameter is plotted against impact force for single and multiple SI tests in Fig. 21. ${ }^{13}$ The delamination diameters were calculated for a circle equal in area to the overall extent of damage measured on C-scan images. These quasiisotropic, uniweave composites were not stitched. In a single test, the specimen is only loaded and ultrasonically scanned once; but, in multiple tests, the specimen is loaded and scanned more than once with the maximum load increasing on each successive loading. The results in Fig. 21 for single and multiple tests are in agreement, indicating that multiple tests can be used to greatly reduce the number of specimens for a given number of tests. For impact forces between $F_{1}$ and penetration, the damage diameter increases in proportion to impact force. The slope corresponds to $1 / \pi \mathrm{Q}^{*}$, where $Q^{*}$ is a critical value of transverse shear strength per unit length. Thus, $F_{1}$ and $Q^{*}$ can be used as metrics for damage resistance.

Values of $F_{1}$ and $Q^{*}$ are plotted in Figs. 22 and 23 for tape laminates and textile composites. ${ }^{13} \mathrm{SI}$ tests were made with a 1.3-mm-diameter hemispherical indenter, and all of the composites had a nominal thickness of $6.3 \mathrm{~mm}$. Values of $F_{1}$ for the 2-D braids and 3-D weaves were somewhat smaller than those for the uniweaves and tape laminates, 4 to $7 \mathrm{kN}$ compared to 8 to $10 \mathrm{kN}$, respectively. Values of $\mathrm{Q}^{*}$ were about $100 \%$ greater for the IM7/8551-7 tape, the stitched uniweave, and the OS2 3-D weave than the other tapes and textiles. Thus, the stitching and 3-D architecture of OS2 were equivalent to the toughened 8551-7 epoxy.

The LS and TS weaves were layer-to-layer and through-the-thickness angle interlocks, respec- tively. The weaver yarns of the orthogonal interlock (OS) weaves also passed through the thickness but were perpendicular to the weaving plane, much like stitching. The warp, weft, and weaver yarns of the OS1, LS1, and TS1 weaves had twice as many filaments as those of the OS2, LS2, and TS2 weaves. Therefore, 3-D architecture alone was not sufficient to assure improved impact damage resistance.

Impact force is plotted against thickness in Fig. 24 for stitched and nonstitched uniweaves for three levels of damage. ${ }^{14}$ Logarithmic scales were used for convenience. The levels of damage were nonvisible damage $\left(F_{i}\right)$, barely visible damage $(0.13-$ $\mathrm{mm}$ dent), and visible damage (2.5-mm dent). Thicknesses ranged from 16 to 48 plies. In all cases, the impact force increased approximately with thickness to the $3 / 2$ power. The effect of the stitching on impact force changed with level of damage - a negative effect for nonvisible damage and a positive effect for visible damage.

Damage resistance $Q^{*}$ is plotted against thickness in Fig. 25 for stitched and nonstitched uniweaves. For the thinnest coupons, the stitching gave little benefit, but the benefit increased dramatically with thickness.

Post-impact tension and compression strengths are plotted in Fig. 26 for visible impact damage. ${ }^{15}$ Impacts were made using 5.4-kg falling weights with a 13-mm-diameter hemispherical indenter. Visible impact damage was represented by $2.5-\mathrm{mm}$ dents. SI tests were used to determine falling weight energies to produce the dents. The strengths were normalized by undamaged strengths for convenience. For the braids and 3-D weaves, tension strength ratios were generally greater than compression strength ratios. For the uniweave textiles, however, tension strength ratios were less than compression strength ratios especially for the stitched uniweave. Strength ratios were least for the nonstitched uniweaves. Stitching improved the compression strength ratio far more than the tension strength ratio.

The current test methods for post-impact strength do not account for boundary effects and were not considered acceptable for developing allowables for specific impact energies. ${ }^{7}$ The boundaries affect the impact problem in the following two primary ways: (1) the size of damage resulting from a given kinetic energy and mass and (2) the residual strength for a given damage size. Most of the effect on damage size can be eliminated by using a detectable damage metric such as dent depth rather than a specific impact energy. However, for 
detectable dents, damage size can be relatively large compared to coupon size; and, without finite width correction factors, coupon strengths can be unrealistically low. For example, the test sections of the specimens in Fig. 26 were 10 by $10 \mathrm{~cm}$, and the damage sizes in C-scans ranged from $4.8 \mathrm{~cm}$ to $6.8 \mathrm{~cm}^{12}$ If the impact damage was equivalent to an open hole in a finite width sheet of infinite length, the strengths should have been corrected by factors ranging from 1.5 to 2.3 , respectively. The C-scan damage sizes indicate size of matrix damage. Because fiber damage is much smaller in size than matrix damage, the compression strengths in Fig. 26 may have been unduly less than tension strengths due to the use of small coupons.

\section{Analytical Models}

Cox and Flanagan compiled a handbook of analytical methods for textile composites. ${ }^{16}$ In this handbook they discussed the choice of textile and tape laminates, failure mechanisms, various mathematical concepts and associated computer codes for predicting elastic constants and thermal expansion coefficients, and strength predictions. The capabilities of the computer codes are given in Fig. 27.

The SAWC computer code in Fig. 27 computes stresses and initiation and progression of damage in plain weave textiles. A single unit cell is modeled using finite elements. A stress-strain curve calculated using this code is shown in Fig. 28 for a AS4/3501-6 plain weave composite. ${ }^{5}$ The initial failure is at point "a" where the stress $\sigma 22$ in the fill tow exceeds its allowable. (The fill tow is oriented transverse to the applied load.) At point $b$, the damage due to $\sigma 22$ spreads; and, at point $\mathrm{c}$, the resin in the warp yarn fails where $\sigma 33$ and $\sigma 13$ stresses exceed their allowables. The large drop in load is caused by the large crimp angle, analogous to a unidirectional tape laminate loaded offaxis. With a smaller crimp angle, the load drop would have been smaller, and loading could have continued until the fibers in the warp tows fail.

The TEXCAD computer code in Fig. 27 can be executed on a PC or Macintosh type desktop computer. This code does not use finite elements but assumes uniform strain throughout the unit cell and superimposes strains due to flexure of the crimped yarns. Weaves and braids can be analyzed using TEXCAD. Graphs of moduli and strength from experiments and TEXCAD are compared in Figs. 29 and 30 for one of the triaxial braids. The predictions and experiments are in good agreement. In general, agreement was better for moduli than strength.

\section{Coupon-Type Data Base}

A coupon-type data base was compiled from the results generated by the ACT program. ${ }^{17}$ The data documentation for this data base satisfies the requirements laid out in the MIL-HDBK-17. The following properties are included: elastic moduli; unnotched, open-hole, filled-hole, tension and compression strengths for uniaxial loads; unnotched tension and compression strengths for biaxial loads; and bearing strengths. The following materials are represented: 2-D triaxial braids, 3-D multiaxial braids, stitched uniweave, 8-harness and 3D interlock weaves, stitched multi-axial warp knits, and uniweaves. This data base is available in the following two formats: a summary or executive version in Microsoft Excel for Apple $_{\circledast}$ Macintosh $_{\circledast}$ Series and Windows ${ }^{\mathrm{m}}$ Series operating systems and an unabridged version in MSC/MVISION ${ }_{\circledast}$ for UNIX Series operating systems. These are available at URL http://techreports.larc.nasa.gov/ltrs/96/NASA-96cr4747.refer.html.

\section{Concluding Remarks}

Textile reinforced composites and their application potentials to aircraft primary structure are being explored in the NASA Advanced Composites Technology Program (ACT). Structural elements, which are part of the primary structure, include fuselage stiffened panels, frames, and window belts, and wing upper and lower covers, stiffener and spar caps, intercostal clips, and landing gear attachments. Some of the structural elements are stitched to improve damage tolerance. Either resin transfer molding or resin film infusion processes are used to impregnate the preforms. Analytical models are under development to predict resin flow and cure of textile reinforced composites. The developments in stitching, weaving and knitting have lead to composite structures that are durable and damage tolerant, light-weight, and costeffective.

NASA in-house research, with the help of university research grants, has developed a basic mechanics underpinning of textile composites. These studies led to the development of (1) test methods for measuring material properties and design allowables, (2) mechanics models to predict the effects of fiber preform architecture and constituent properties on engineering moduli, stiffness, strength, damage resistance, and fatigue life, and (3) an electronic data base of coupon type test data.

\section{$\underline{\text { References }}$}


${ }^{1}$ llcewicz, L. B., Smith, P. J., Walker, T. H., and Johnson, R. W., "Advanced Technology Commercial Fuselage Structure," Proceedings of the First NASA ACT Conference, NASA CP-3104, Part 1, 1991, pp. 127-155.

2Jackson, Anthony C., Barrie, Ronald E., and Chu, Robert L., "Textile Composite Fuselage Structures Development," Proceedings of the Third NASA ACT Conference, NASA CP-3178, Part 1, 1992, pp. 79-96.

${ }^{3}$ Loos, A. C., MacRae, John D., Kranbuehl, David E., Husmann, Christopher H., Rohwer, Kim, and Deaton, Jerry W., "Resin Film Infusion (RFI) Process Simulation of Complex Wing Structures," Proceedings of the Fifth NASA/DoD Advanced Composites Technology Conference, NASA CP-3294, May 1995, pp. 811-833.

${ }^{4}$ Masters, John E., "Strain Gage Selection Criteria for Textile Composite Materials," NASA CR198286, Feb. 1996.

${ }^{5}$ Poe, Jr., C. C., and Harris, C. E., "Mechanics Methodology for Textile Preform Composite Materials," Proceedings of the Sixth NASA DoD Advanced Composites Technology Conference, NASA CP-3326, Part 1, 1996, pp. 95-130.

${ }^{6}$ Masters, John E., and Portanova, Marc A., "Standard Test Methods for Textile Composites," NASA CR-4751, Sept. 1996 (available at URL http://techreports.larc.nasa.gov/ltrs).

${ }^{7}$ Poe, C. C., Jr., "Mechanics methodology for textile preform composite materials," Proceedings of the 28th International SAMPE Technical Conference, Nov. 1996, pp. 324-338.

${ }^{8}$ Norman, Timothy L., Anglin, Colin, Gaskin, David, and Patrick, Mike, "Effect of Open Hole on Tensile Failure Properties of 2D Triaxial Braided Textile Composites and Tape Equivalents," NASA CR-4676, June 1995.

${ }^{9}$ Minguet, Pierre J., and Gunther, Christian K., "A Comparison of Graphite/Epoxy Tape Laminates and 2-D Braided Composites Mechanical Properties," NASA CR-4610, July, 1994.

${ }^{10}$ Jackson, Wade C. and Ifju, Peter, G., "Throughthe-Thickness Tensile Strength of Textile Composites," Composite Materials: Testing and Design (Twelfth Volume), ASTM STP 1274, R. B. Deo and C. R. Saff, Eds., American Society for Testing and Materials, 1996, pp. 218-238.

${ }^{11}$ Jackson, W. C., and Poe, Jr., C. C., "The Use of Impact Force as a Scale Parameter for the Impact Response of Composite Laminates," Journal of Composites Technology Research, Vol. 15 (No. 4), Winter 1993, pp. 282-289.

${ }^{12}$ Portanova, M. A., "Evaluation of the Impact Response of Textile Composites," NASA CR198265, Dec. 1995.

${ }^{13}$ Jackson, Wade C., and Portanova, Marc A., "Impact Damage Resistance of Textile Compos-

ites," Proceedings of the 28th International SAMPE Technical Conference, Nov. 1996, pp. 339-350.

${ }^{14}$ Poe, Jr. C. C., "Residual Strength of Composite Aircraft Structures with Damage," ASM Handbook, Vol. 19, Fatigue and Fracture, 1996, pp. 920-935.

${ }^{15}$ Portanova, M. A., "Impact Damage Tolerance of Textile Composites," Proceedings of the 28th International SAMPE Technical Conference, Nov. 1996, pp. 351-362.

${ }^{16}$ Cox, Brian N., and Flanagan, Gerry, "Handbook of Analytical Methods for Textile Composites," NASA CR-4750, 1997 (available at URL http://techreports.larc.nasa.gov/ltrs).

${ }^{17}$ Delbrey, Jerry, "Database of Mechanical Properties of Textile Composites," NASA CR-4747, Aug. 1996 (available at URL http://techreports.larc.nasa.gov/ltrs).

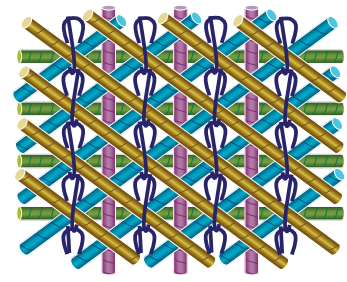

Multiaxial warp knit (stitched \& unstitched)

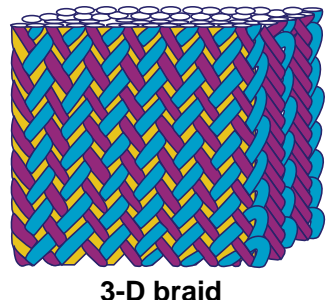

3-D braid

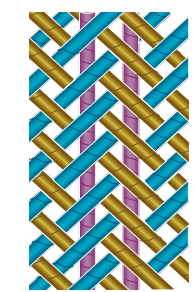

2-D triaxial braid (stitched \& unstitched)

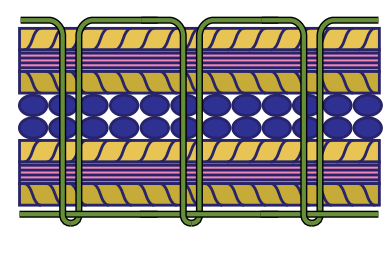

Knitted/stitched

Fig. 1. Textile material forms evaluated. 


\begin{tabular}{|c|c|c|}
\hline Textile Process & Advantages & Limitations \\
\hline $\begin{array}{l}\text { Low Crimp } \\
\text { Uniweave }\end{array}$ & $\begin{array}{l}\text { High in-plane properties } \\
\text { Good tailorability } \\
\text { Highly automated preform } \\
\text { fabrication process }\end{array}$ & $\begin{array}{c}\text { Low transverse and } \\
\text { out-of-plane properties } \\
\text { Poor fabric stability } \\
\text { Labor intensive } \\
\text { ply lay-up }\end{array}$ \\
\hline $\begin{array}{l}\text { 2-D Woven } \\
\text { Fabric }\end{array}$ & $\begin{array}{c}\text { Good in-plane properties } \\
\text { Good drapability } \\
\text { Highly automated preform } \\
\text { fabrication process } \\
\text { Integrally woven shapes possible } \\
\text { Suited for large area coverage } \\
\text { Extensive data base }\end{array}$ & $\begin{array}{l}\text { Limited tailorability } \\
\text { for off-axis } \\
\text { properties } \\
\text { Low out-of-plane } \\
\text { properties }\end{array}$ \\
\hline 3-D Woven Fabric & \begin{tabular}{|c|}
$\begin{array}{c}\text { Moderate in-plane and out-of-plane } \\
\text { properties }\end{array}$ \\
$\begin{array}{c}\text { Automated preform fabrication process } \\
\text { Limited woven shapes possible }\end{array}$ \\
\end{tabular} & $\begin{array}{l}\text { Limited tailorability } \\
\text { for off-axis } \\
\text { properties } \\
\text { Poor drapability }\end{array}$ \\
\hline 2-D Braided Preform & $\begin{array}{c}\text { Good balance in off-axis properties } \\
\text { Automated preform fabrication process } \\
\text { Well suited for complex curved shapes } \\
\text { Good drapability }\end{array}$ & $\begin{array}{c}\text { Size limitation due to } \\
\text { machine availability } \\
\text { Low out-of-plane } \\
\text { properties }\end{array}$ \\
\hline 3-D Braided Preform & $\begin{array}{l}\text { Good balance in in-plane and } \\
\text { out-of-plane properties } \\
\text { Well suited for complex shapes }\end{array}$ & $\begin{array}{c}\text { Slow preform } \\
\text { fabrication process } \\
\text { Size limitation due to } \\
\text { machine availability } \\
\end{array}$ \\
\hline $\begin{array}{l}\text { Multiaxial } \\
\text { Warp Knit }\end{array}$ & $\begin{array}{l}\text { Good tailorability for balanced } \\
\text { in-plane properties } \\
\text { Highly automated preform } \\
\text { fabrication process } \\
\text { Multi-layer high throughput } \\
\text { material suited for large area coverage }\end{array}$ & $\begin{array}{l}\text { Low } \\
\text { out-of-plane } \\
\text { properties }\end{array}$ \\
\hline Stitching & $\begin{array}{l}\text { Good in-plane properties } \\
\text { Highly automated process } \\
\text { provides excellent damage } \\
\text { tolerance and out-of-plane strength } \\
\text { Excellent assembly aid }\end{array}$ & $\begin{array}{l}\text { Small reduction in } \\
\text { in-plane properties } \\
\text { Poor accessibility } \\
\text { to complex } \\
\text { curved shapes }\end{array}$ \\
\hline
\end{tabular}

Fig. 2. Application potential of textile reinforced composite materials for aircraft structures.

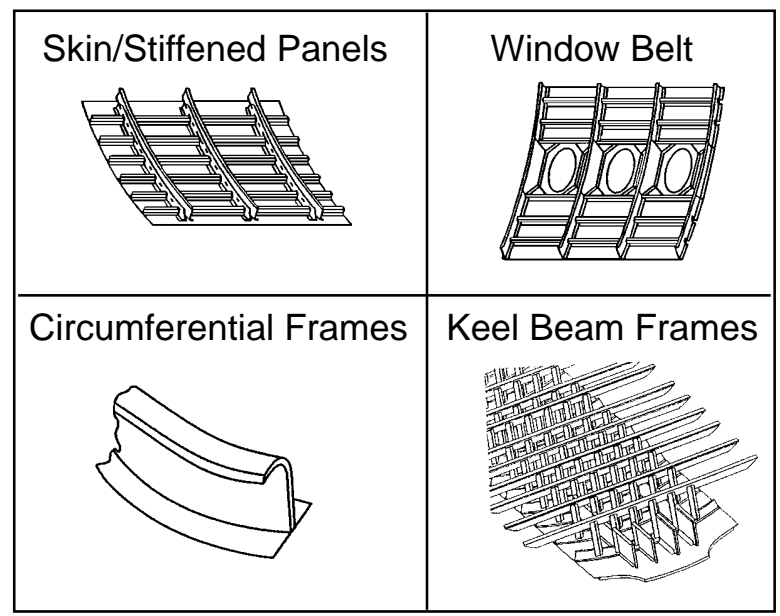

Fig. 3. Application of textile reinforced composites in fuselage structures.

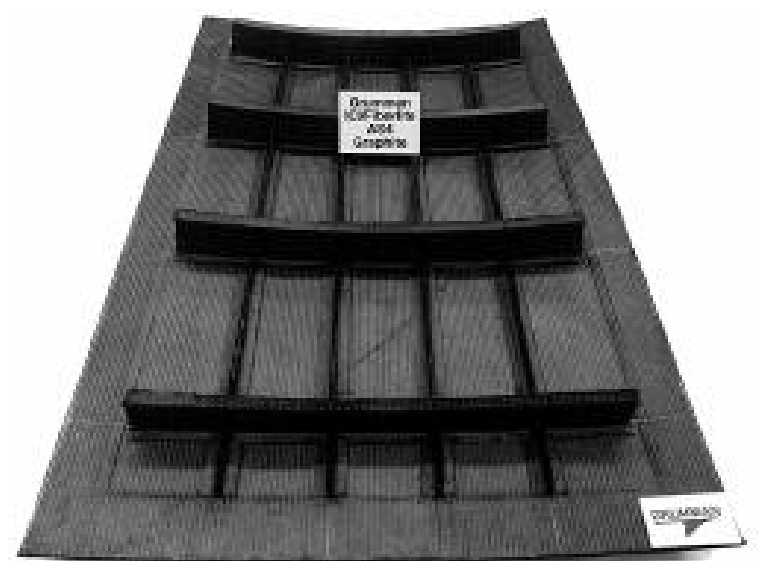

Fig. 4. Woven/stitched lower fuselage side panel preform.

3-D Through-The-Thickness Braid

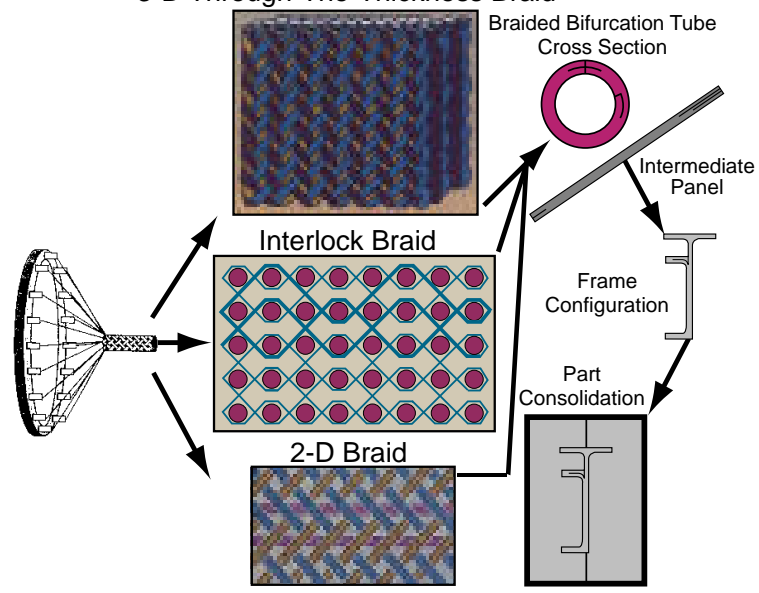

Fig.5. Fabrication process for braided fuselage frames.

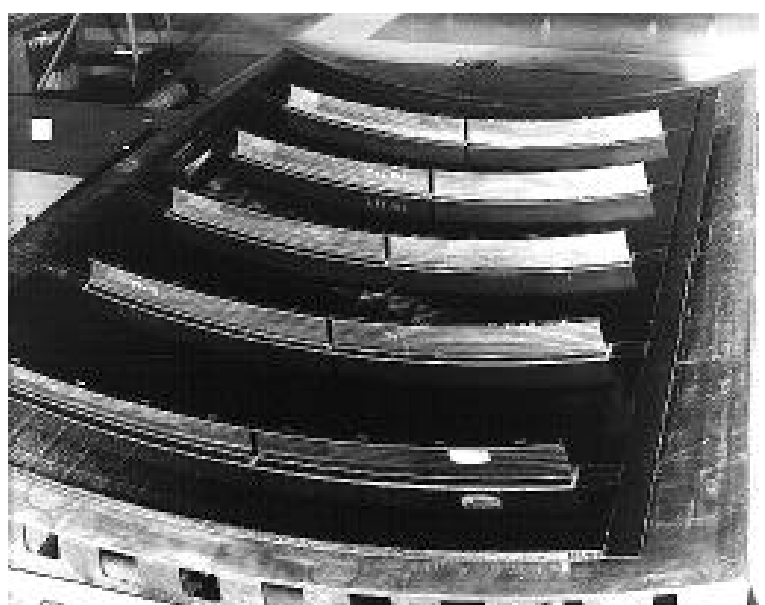

Fig. 6. Curved textile frames for fuselage keel structure. 


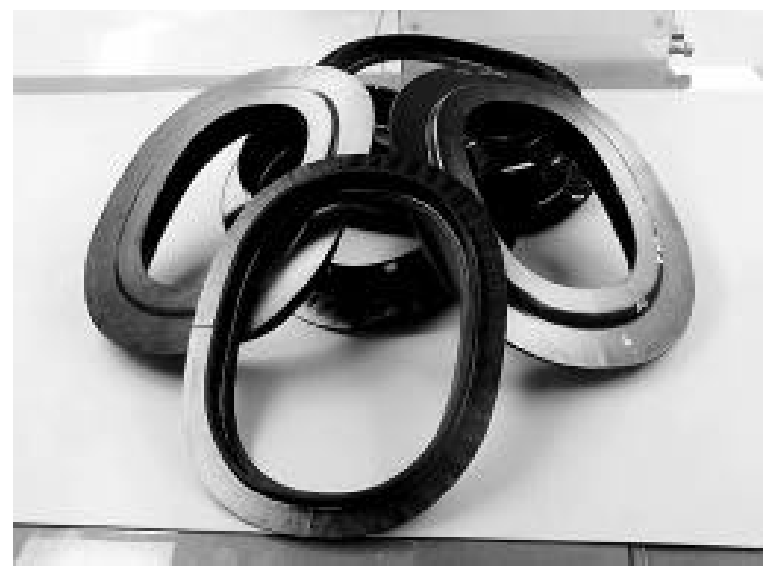

Fig. 7. Braided and woven fuselage window frames.

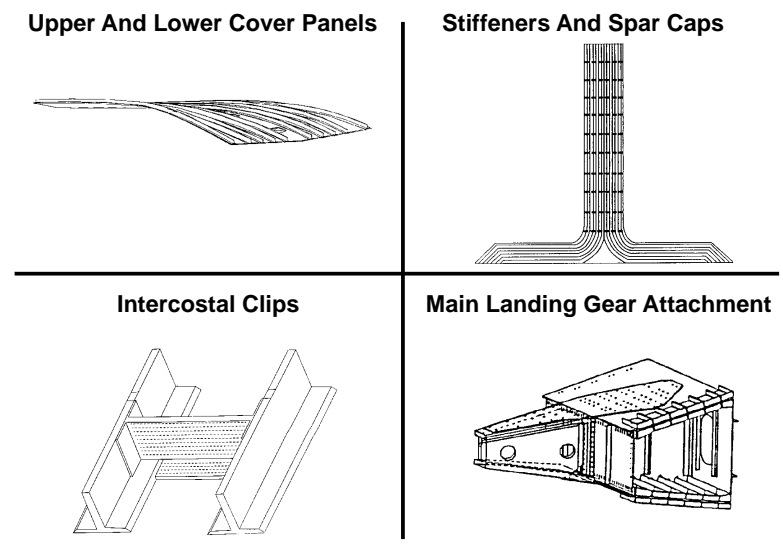

Fig. 8. Application of textile reinforced composites in wing structures.

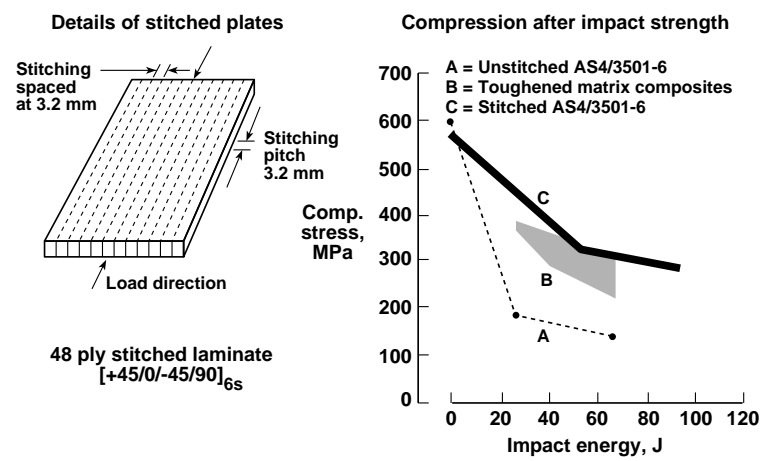

Fig. 9. Effects of stitching on damage tolerance of composite materials.

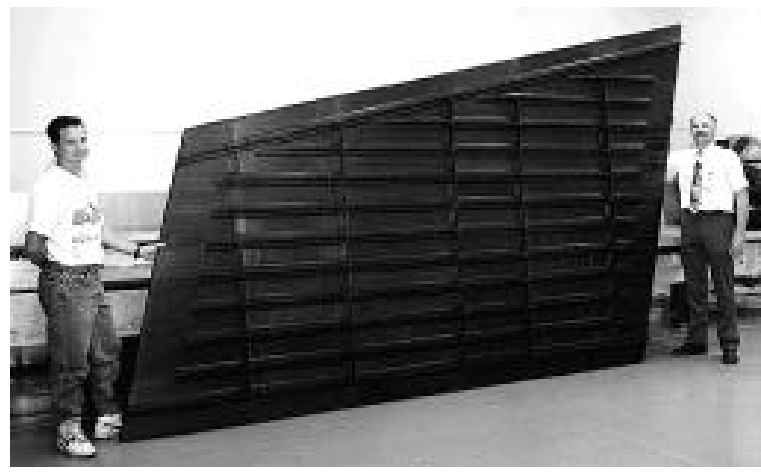

Fig. 10. Stitched/resin film infused wing stub box cover panel.

\begin{tabular}{|c|c|}
\hline - Fabric geometry/architecture & $\begin{array}{l}\text { Resin Infiltration Model } \\
\text { - Time, temperature, pressure } \\
\text { - Preform permeability } \\
\text { - Viscosity profile }\end{array}$ \\
\hline $\begin{array}{l}\text { Cure Kinetics } \\
{ }_{\mathrm{c}} \mathrm{C}_{\mathrm{c}} \frac{\partial \mathrm{T}}{\partial \mathrm{t}}=\frac{\partial}{\partial z}\left(\mathrm{~K}_{\mathrm{c}} \frac{\partial \mathrm{T}}{\partial \mathrm{z}}\right)+\dot{\mathrm{H}}_{\mathrm{c}} \\
\text { - Heat transfer analysis } \\
\text { - Viscosity model } \\
\text { - Degree of cure }\end{array}$ & $\begin{array}{l}\text { Cure Monitoring/Feedback Control } \\
\text { - Dielectric sensors } \\
\text { - Realtime feedback control } \\
\text { - Flow visualization } \\
\text { - Verification of infiltration } \\
\text { and cure }\end{array}$ \\
\hline
\end{tabular}

Fig. 11. Processing science of textile reinforced composites.

Ply Drop Off Single Blade Stiffener Preform/Tooling Assembly

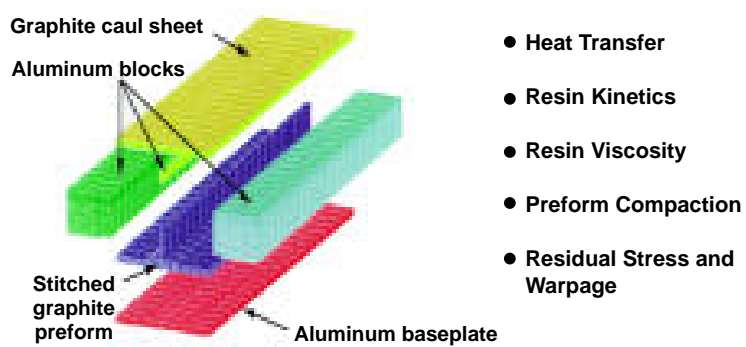

Fig. 12. 3-D resin film infusion model. 


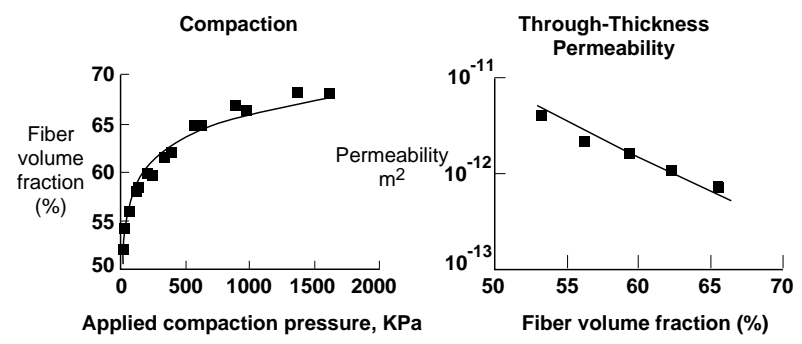

Fig. 13. Compaction and permeability behavior of Saertex multiaxial warp knit fabric.
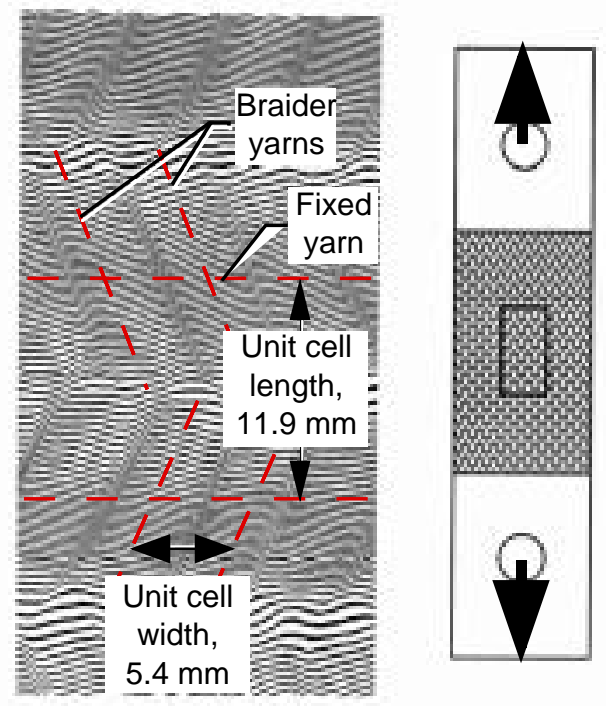

Fig. 14. Vertical displacement field in triaxial braid by Moiré.

\begin{tabular}{|c|c|c|}
\hline $\begin{array}{l}\text { Test method } \\
\text { type }\end{array}$ & Test methods evaluated & $\begin{array}{l}\text { Best test } \\
\text { methods }\end{array}$ \\
\hline \multicolumn{3}{|c|}{ Inplane } \\
\hline $\begin{array}{l}\text { Unnotched } \\
\text { tension }\end{array}$ & $\begin{array}{l}\text { Straight sided (ASTM } \\
\text { D3039) and dog-bone } \\
\text { specimens }\end{array}$ & $\begin{array}{l}\text { Straight } \\
\text { sided } \\
\text { (ASTM } \\
\text { D3039) } \\
\text { specimens }\end{array}$ \\
\hline $\begin{array}{l}\text { Unnotched } \\
\text { compression }\end{array}$ & $\begin{array}{l}\text { NASA Short Block, Modified } \\
\text { IITRI, Boeing OHC, Zabora, } \\
\text { Boeing CAI, NASA ST-4, } \\
\text { and sandwich column }\end{array}$ & Zabora \\
\hline $\begin{array}{l}\text { Open-hole } \\
\text { tension }\end{array}$ & $\begin{array}{l}\text { Straight sided specimen } \\
\text { (ASTM D5766) }\end{array}$ & $\begin{array}{l}\text { Straight } \\
\text { sided } \\
\text { specimen } \\
\text { (ASTM } \\
\text { D5766) }\end{array}$ \\
\hline $\begin{array}{l}\text { Open-hole } \\
\text { compression }\end{array}$ & $\begin{array}{l}\text { NASA Short Block, Modified } \\
\text { IITRI, Boeing OHC, Zabora, } \\
\text { Boeing CAI, NASA ST-4, } \\
\text { and sandwich column }\end{array}$ & Zabora \\
\hline $\begin{array}{l}\text { Filled-hole } \\
\text { tension }\end{array}$ & $\begin{array}{l}\text { Straight sided specimen } \\
\text { (ASTM D5766) }\end{array}$ & $\begin{array}{l}\text { Straight } \\
\text { sided } \\
\text { specimen } \\
\text { (ASTM } \\
\text { D5766) }\end{array}$ \\
\hline Bolt bearing & $\begin{array}{l}\text { Boeing Unstabilized Single } \\
\text { Shear, Boeing Stabilized } \\
\text { Single Shear, and Boeing } \\
\text { Double Shear }\end{array}$ & $\begin{array}{l}\text { Boeing } \\
\text { Stabilized } \\
\text { Single } \\
\text { Shear }\end{array}$ \\
\hline Shear & $\begin{array}{l}\text { Tube Torsion, Rail Shear, } \\
\text { and Compact Shear (24) }\end{array}$ & $\begin{array}{l}\text { None totally } \\
\text { satisfactory }\end{array}$ \\
\hline \multicolumn{3}{|c|}{ Out-of-plane } \\
\hline $\begin{array}{l}\text { Tnterlaminar } \\
\text { tension }\end{array}$ & $\begin{array}{l}\text { C- andL-Shape Bend and } \\
\text { Four Point Bend }\end{array}$ & $\begin{array}{l}\text { Four Point } \\
\text { Bend } \\
\text { (strength } \\
\text { only) } \\
\end{array}$ \\
\hline
\end{tabular}

Fig. 15. Test methods evaluated and selected for textiles.

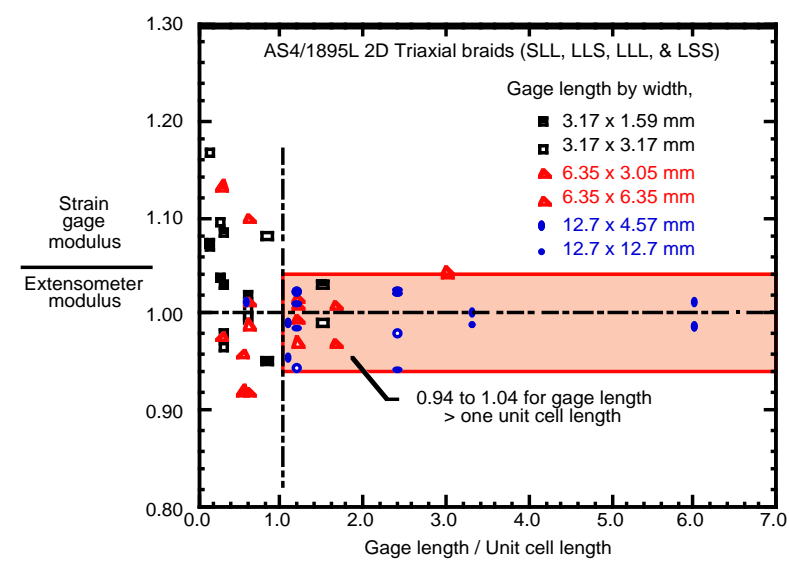

Fig. 16. Effect of gage length on modulus of stress-strain curves. 


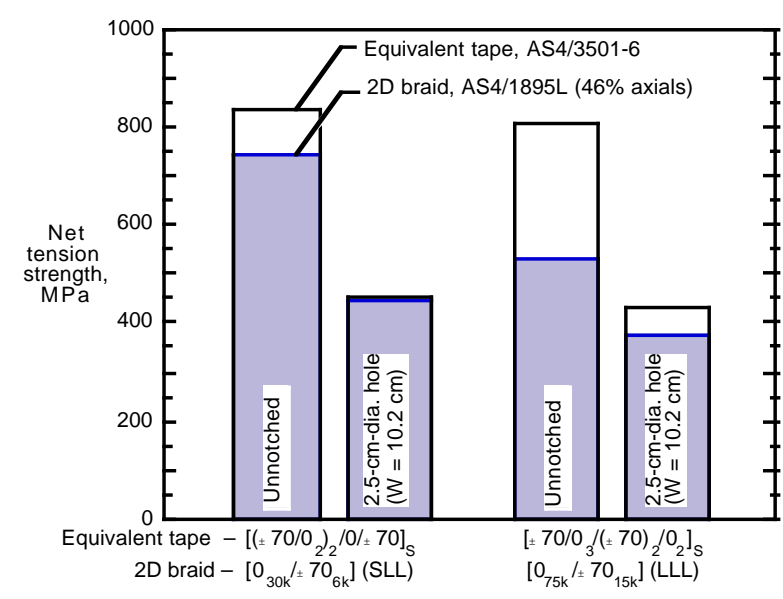

Fig. 17. Open hole strengths of braids and equivalent tape laminates.

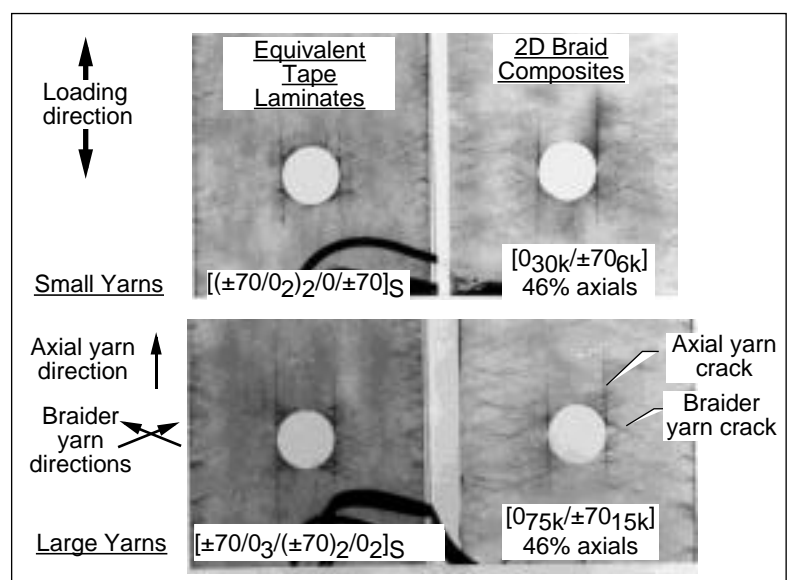

Fig. 18. X-rays of braids and equivalent tape laminates at $75 \%$ of ultimate load.

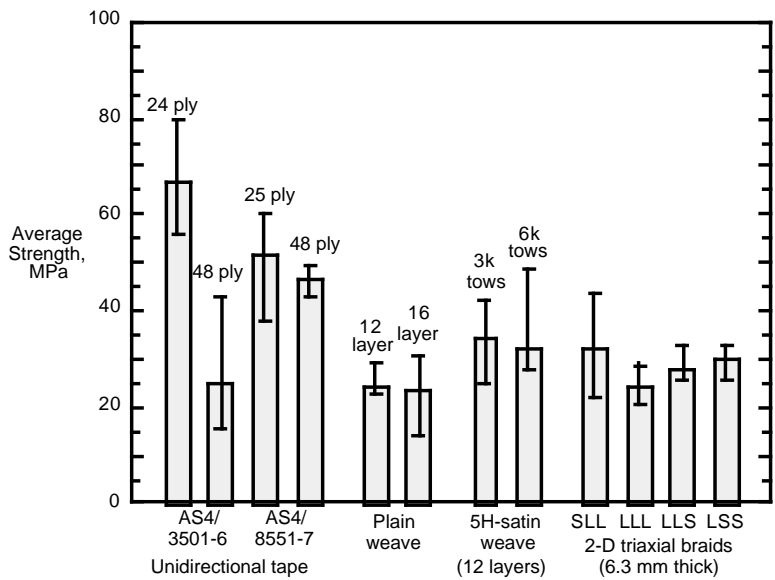

Fig. 19. Through-the-thickness tension strength by bend tests.

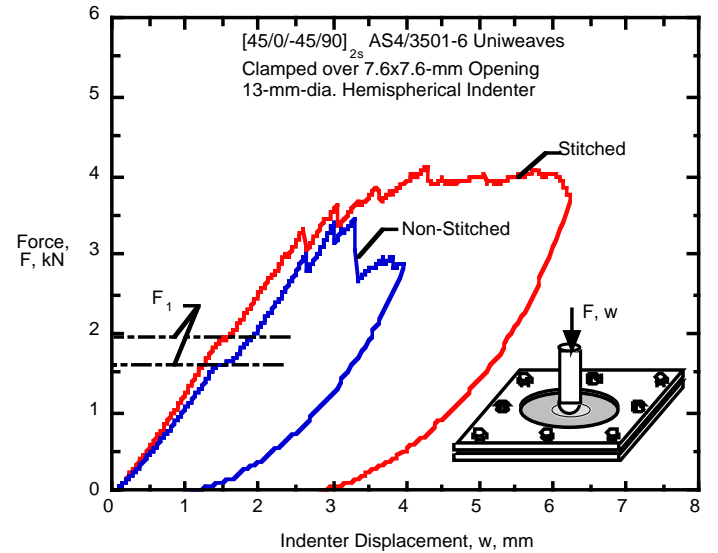

Fig. 20. Static indentation tests.

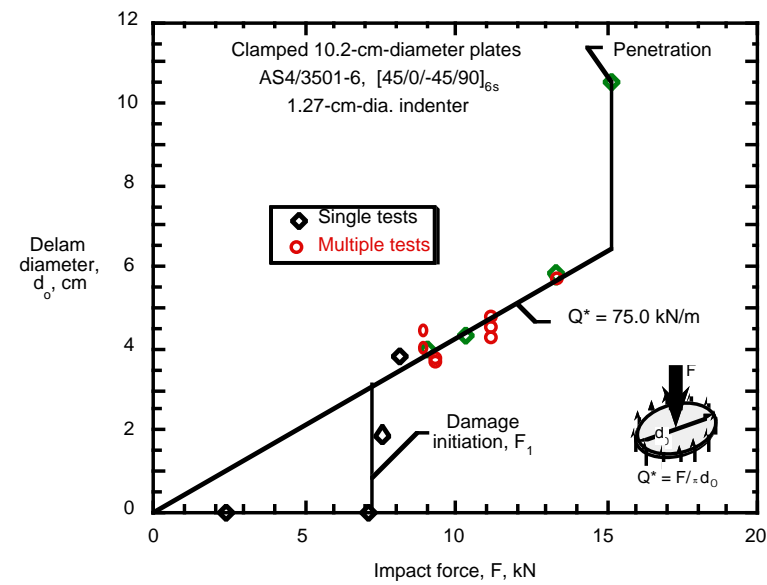

Fig. 21. Damage resistance.

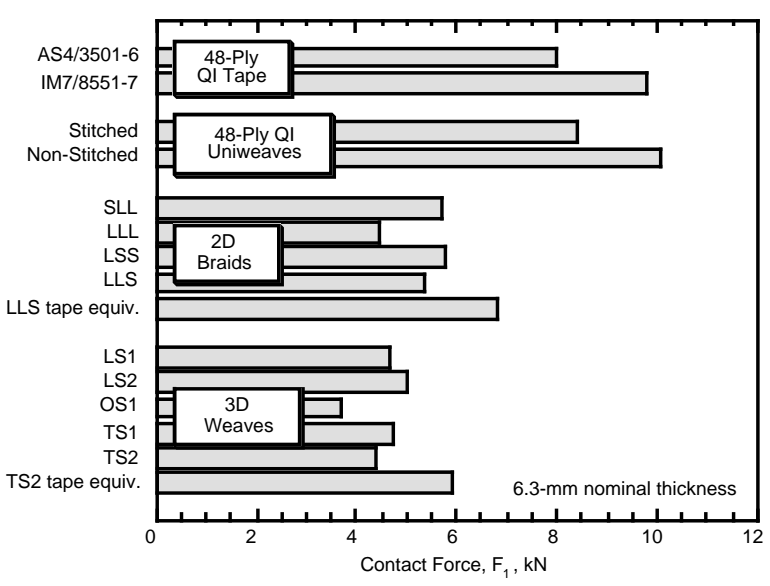

Fig. 22. Damage initiation summary. 


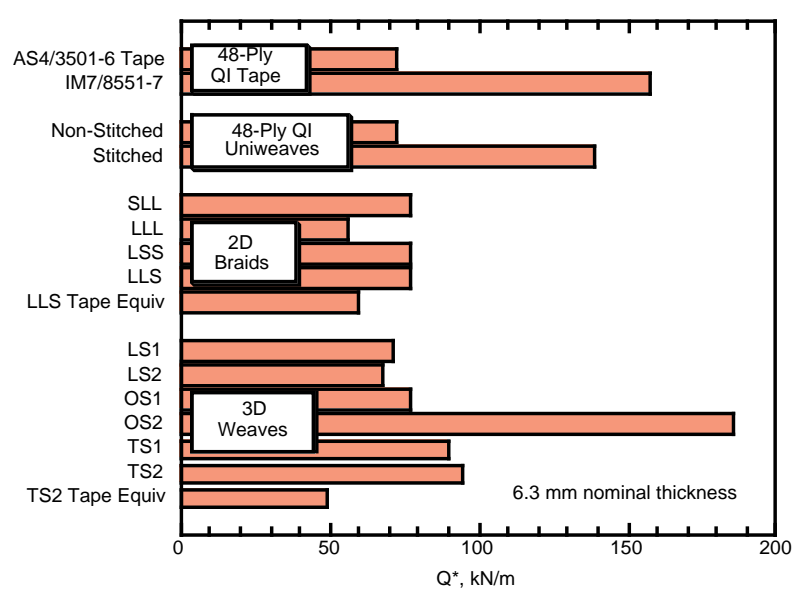

Fig. 23. Damage resistance summary.

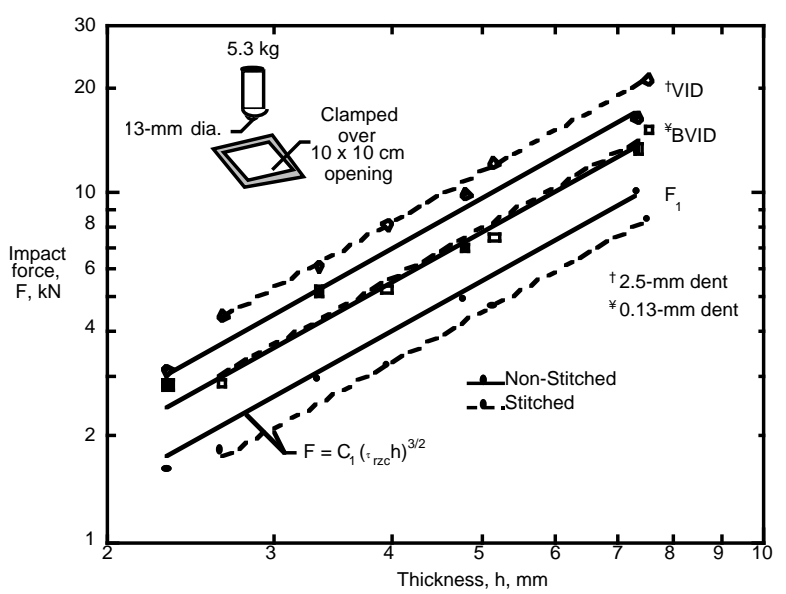

Fig. 24. Impact force to cause damage for various thicknesses.

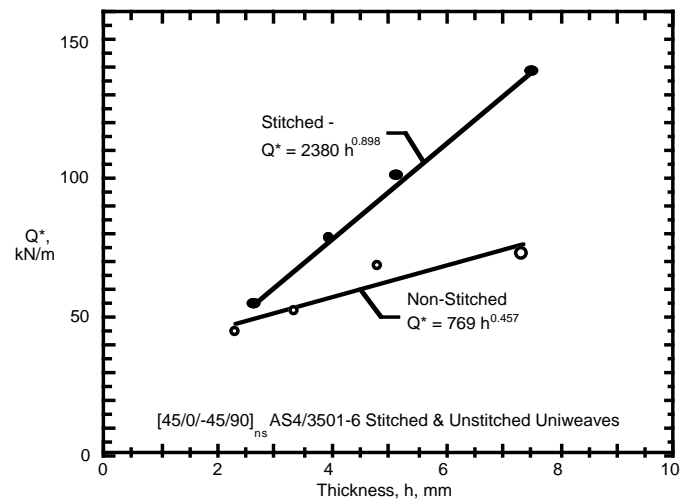

Fig. 25. $Q^{*}$ for various thicknesses.

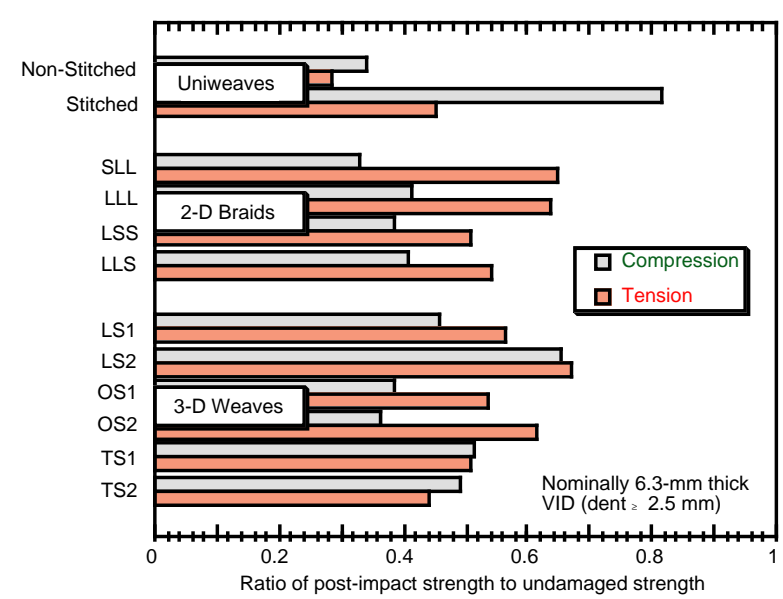

Fig. 26. Post-impact strengths.

\begin{tabular}{|c|c|c|c|c|c|c|c|}
\hline ㅇํㅇ & 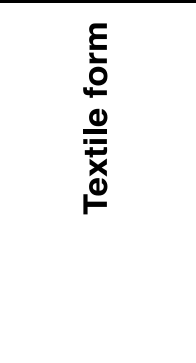 & 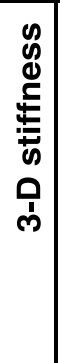 & 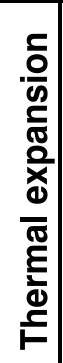 & 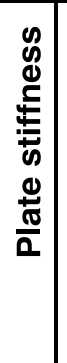 & 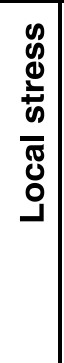 & 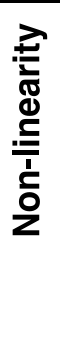 & 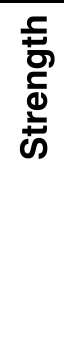 \\
\hline PW & $\begin{array}{c}\text { Plain } \\
\text { weaves }\end{array}$ & & & & & & \\
\hline SAT5 & $\begin{array}{c}5 \text { harness } \\
\text { satin }\end{array}$ & & & & & & \\
\hline SAT8 & $\begin{array}{c}8 \text { harness } \\
\text { satin }\end{array}$ & & v & v & & & \\
\hline $\begin{array}{l}\text { CCM- } \\
\text { TEX }\end{array}$ & $\begin{array}{l}\text { 3-D weave } \\
\& 2-\& 4- \\
\text { step braids }\end{array}$ & $\checkmark$ & & & & & v \\
\hline$\mu$ Tex-10 & General & v & v & & & & \\
\hline${ }_{\mu}$ Tex-20 & $\begin{array}{l}\text { User de- } \\
\text { fined }\end{array}$ & $\checkmark$ & $\checkmark$ & & & & \\
\hline SAWC & $\begin{array}{l}\text { plain weave } \\
\text { (FE code) }\end{array}$ & $\checkmark$ & & & v & $a_{v}$ & v \\
\hline TEXCAD & $\begin{array}{c}2-D \text { weaves } \\
\& \\
\text { 2-D braids }\end{array}$ & $\checkmark$ & v & & & $b_{v}$ & v \\
\hline WEAVE & 3-D weaves & v & & & & & \\
\hline BINMOD & 3-D weaves & $v$ & & & & v & $c_{v}$ \\
\hline
\end{tabular}

aStiffness discounting.

bShear hardening and stiffness discounting. cNot directly.

Fig. 27. Computer code capabilities. 


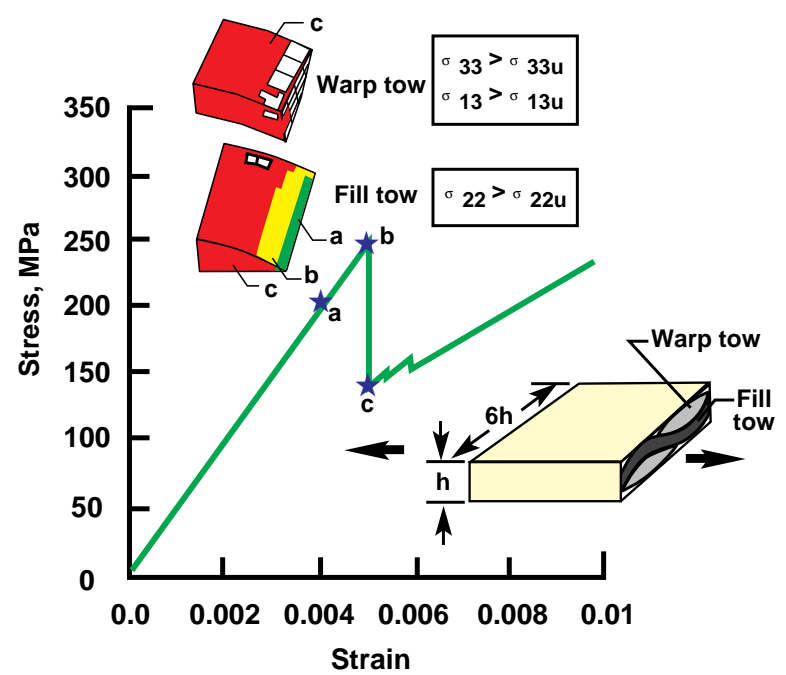

Fig. 28. 3-D finite element analysis of 2-D weave.

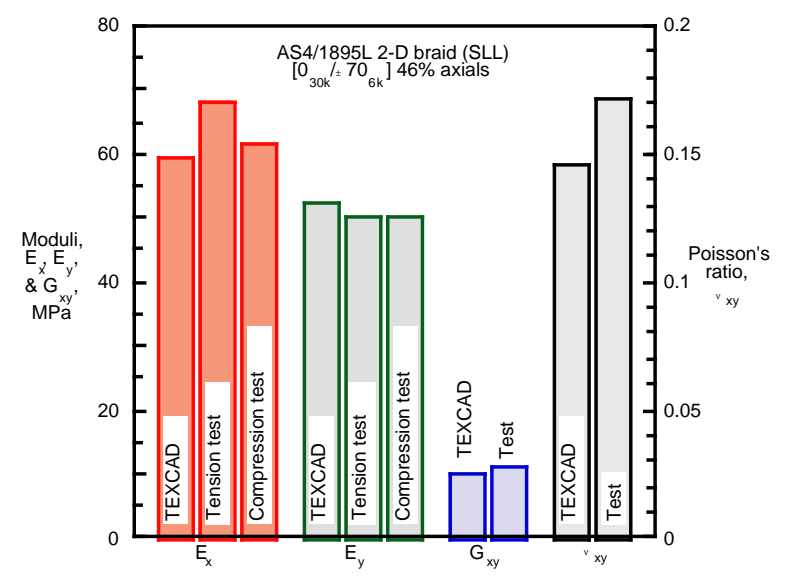

Fig. 29. Moduli by TEXCAD.

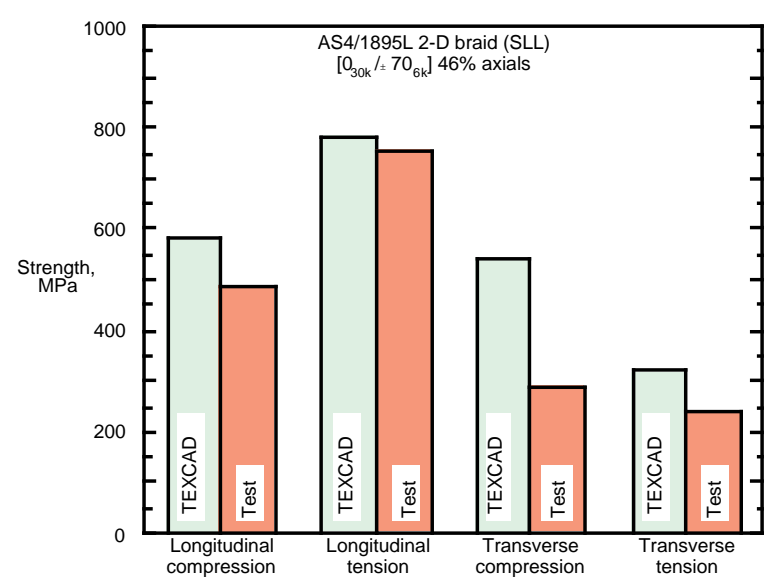

Fig. 30. Strengths by TEXCAD. 